\title{
ANALISIS STRES KERJA DAN UPAYA INTERVENSI PSIKOLOGI KEREKAYASAAN DALAM MENGATASI STRES KERJA NELAYAN TRADISIONAL TANJUNG PENI CITANGKIL DAN LELEYAN GROGOL PESISIR PANTAI CILEGON
}

\author{
Antonius D. Robinson Manurung ${ }^{1}$, Yosephin Sri Sutanti $S^{2}$ dan Dudi Adam H. ${ }^{3}$ \\ ${ }^{1}$ Program Studi Psikologi, Fakultas Psikologi, Universitas Mercu Buana, Jakarta \\ ${ }^{2}$ Departemen K3, Fakultas Kedokteran, Universitas Kristen Krida Wacana, Jakarta \\ ${ }^{3}$ Tim Kesehatan Kerja Kota Cilegon
}

Email: antonius.manurung@mercubuana.ac.id

\begin{abstract}
Abstrak
Penelitian ini bertujuan untuk mengetahui dan menganalisis stres kerja nelayan tradisional Tanjung Peni Citangkil dan Leleyan Grogol, Pesisir Pantai Cilegon. Selanjutnya, berdasarkan hasil temuan dikembangkan upaya intervensi psikologi kerekayasaan sebagai cara mengatasi stres kerja nelayan tradisional.

Populasi dalam penelitian berjumlah sekitar 4000 nelayan; berdasarkan teknik purposive sampling diperoleh 84 responden, nelayan Tanjung Peni Citangkil (45) dan Leleyan (39).

Teknik pengumpulan data menggunakan kuesioner, wawancara, alat deteksi stres (dikenal dengan alat HRV-Heart Rate Variability). Skala stres kerja diadaptasi dan dimodifikasi penulis dari konsep dan alat ukur Igor (1997). Teknik wawancara menggunakan pedoman wawancara stres kerja. Sedangkan alat deteksi stres kerja HRV mengukur frekuensi domain HRV yang digunakan untuk mengkla sifikasikan kondisi stres mental individu.

Hasil penelitian menunjukkan stres kerja nelayan relatif cukup tinggi deng an nilai mean 53, 385. Berdasarkan nilai t diketahui bahwa stres kerja nelayan Leleyan, Grogol lebih tinggi dibandingkan dengan nelayan Tanjung Peni, Citangkil. Data deskriptiftersebut didukung hasil tes HRV dalam stress resistance (coping stress), dan stress index (psikis), dan fatigue index. Hasil data wawancara menunjukkan bahwa hal yang menyebabkan stres kerja pada nelayan tradisional di pesisir Pantai Cilegon Banten adalah lingkungan kerja yang kurang kondusif, mencakup suhu udara, pencahayaan, goncangan, dan kebisingan, cara kerja yang kurang ergonomis, dan manajemen kesehatan dan keselamatan kerja (K3) yang relatifburuk.
\end{abstract}

Kata kunci : stres kerja, nelayan, heart rate variability, intervensi psikologi kerekayasaan

\section{Pendahuluan}

Indonesia sebagai negara maritim dengan salah satu ciri pekerja yang banyak bekerja sebagai nelayan memiliki porsi tersendiri, karena hampir $60 \%$ penduduk Indonesia bertempat tinggal di daerah pesisir dan pedesaan. Data statistik menunjukkan bahwa terdapat 8 ribu desa pesisir yang tersebar pada 300 kabupaten/kota pesisir, dan 234 juta jiwa penduduk Indonesia, 67 juta bekerja pada bidang informal, dan 30\% diantaranya nelayan (Pusat Data dan Informasi Kesehatan RI, 2015).

Pada sumberdaya tenaga kerja yang berbasis pada mata pencaharian sebagai nelayan, perubahan iklim memicu munculnya stres kerja akibat gagal panen atau harga yang turun atau sumber daya lahan yang tidak memadai. Stres kerja diduga juga terjadi pada nelayan yang diakibatkan oleh rusaknya sumber 
mata pencaharian mereka akibat perubahan ekologis. Kondisi ini kemudian menyebabkan munculnya respon dan upaya untuk beradaptasi dalam menghadapi krisis (Makara, 2012).

Stres kerja adalah respon individu terhadap stressor yang ada pada pekerjaan yang dapat menyebabkan seseorang tidak berfungsi optimal, reaksi yang dapat terjadi yaitu dapat berupa reaksi fisik, psikologis atau tingkah laku (Munandar, 2001).

Gangguan emosi atau yang biasa disebut dengan stres merupakan suatu reaksi seseorang terhadap tekanan yang berlebihan atau tuntutan di tempat kerja yang bersifat merugikan. Stres kerja juga dijelaskan sebagai proses psikologis yang terjadi sebagai konsekuensi dari perilaku atau kejadian pada lingkungan kerja yang menimbulkan akibat-akibat khusus secara psikologis, fisiologis, dan perilaku individu.

Dari fenomena yang terjadi di lapangan, peneliti menangkap beberapa pokok masalah nelayan yang menimbulkan kondisi stres yaitu: (1) kondisi alam yang tidak menentu, (2) tingkat pendidikan nelayan yang rendah, (3) pola kehidupan nelayan yang konsumtif, (4) kurang maksimalnya pemasaran hasil tangkapan, (5) program pemerintah yang belum memihak nelayan. Kondisi - kondisi inilah yang pada akhirnya memicu munculnya stres kerja nelayan yang pada akhirnya berpengaruh pada produktivitas kerja nelayan.

Masalah pokok nelayan yang berdampak pada munculnya stres kerja merupakan tantangan tersendiri untuk dicarikan jalan pemecahannya. Itulah yang menjadi dasar dan alasan kuat mengapa penelitian ini dilakukan sehingga pada akhirnya para nelayan dapat terbantu untuk mengatasi stres kerja dengan mengembangkan upaya intervensi psikologi kerekayasaan.

\section{Kajian Pustaka}

\section{Stres Kerja}

Pemahaman mengenai stres kerja perlu diawali dengan mengetahui stres kronis. Stres kronis merupakan salah satu bentuk stres yang terjadi dalam jangka waktu yang lama dan sulit dikendalikan dimana ada situasi yang mengganggu yang sangat sulit untuk diatasi dan lama kelamaaan dapat menimbulkan kerusakan bagi tubuh, pikiran, dan kehidupan individu yang merasakannya (Olvin \& Hesson, 2010). Menurut NIOSH (2000), beberapa penyakit yang berkaitan dengan stres kronis, antara lain: diabetes, hernia, tuberculosis, asma, darah tinggi, penyakit jantung, rematik, epilepsi, glukoma, paralysis, gangguan ginjal, gangguan perbafasan, stroke, anemia, gangguan hati atau pankreas, gangguan kelenjar tiroid, insomnia, gastritis, colitis, sakit punggung, dan alergi.

McEwen (dalam Oxington, 2008) menjelaskan stres sebagai sebuah peristiwa yang mengancam individu sehingga menghasilkan respon secara fisiologi dan perilaku. Pada hakikatnya stres adalah gap antara individual's coping skills dan demand dari lingkungan di mana individu berada (Redfern, Rees, dan Rowlands, 2008).

Selye (dalam Santrock, 2003) membagi proses stres dalam tubuh melalui tiga fase general adaptation syndrome, yaitu : (1) fase I (alarm reaction), (2) fase II (resistance reaction), (3) fase III (exhau stion reaction).

Proses seseorang mengalami stres

- apapun penyebabnya - diungkap Lazarus dan Folkman (dalam Caverley, 2005), melalui 3 (tiga) tahap, yaitu : (1) ketika seseorang menghadapi stressor, dalam tahap paling awal dikenal sebagai primary prevention - ia akan melakukan penaksiran awal atas situasi yang dihadapinya guna mengetahui implikasi stressor tersebut apakah positif, negatif atau netral bagi dirinya; (2) ketika seseorang menganggap bahwa situasi yang dihadapinya penuh tekanan, maka ia akan melakukan penilaian kembali terhadap kemampuannya untuk mengatasi tekanan itu dikenal sebagai secondary appraisal; dan (3) ketika seseorang yang telah mengalami tahap satu dan dua di atas dan tidak mampu mengatasi tekanan yang ada, maka berbagai ketegangan akan muncul, seperti ketegangan psikologis, perilaku dan fisik; ketegangan-ketegangan ini merupakan pertanda jika orang tersebut mengalami stres.

Gangguan emosi atau yang biasa disebut dengan stres merupakan suatu reaksi seseorang terhadap tekanan yang berlebihan atau tuntutan di tempat kerja yang bersifat merugikan (Tarwaka, 2013). 
Lebih jauh, Tarwaka (2013) menjelaskan stres kerja sebagai proses psikologis yang terjadi sebagai konsekuensi dari perilaku atau kejadian pada lingkungan kerja yang menimbulkan akibat-akibat khusus secara psikologis, fisiologis, dan perilaku individu yang bersifat merugikan.

Cox, Griffiths, dan Rial-Gonzlez (2000) telah mengidentifikasi efek stres, yang mungkin muncul, meliputi dampak subyektif (subjective effect), dampak perilaku (behavioral effect), dampak kognitif (cognitive effect, dampak fisiologis (Physiological effect), dampak kesehatan (health effect), dan dampak organisasi (organizational effect).

\section{Heart Rate Variability (HRV)}

Salah satu alat yang digunakan untuk diagnosis stres adalah $H R V$. $H R V$ merupakan variasi dari beatto-beat denyut jantung yang memberikan gambaran gejala fisiologis dari denyut jantung (heart rate) dengan variasinya dalam interval waktu (Novani \& Prihatmanto, 2016). Lebih jauh Novani dan Prihatmanto (2016) mengemukakan bahwa analisis $H R V$ memberikan suatu informasi tentang modulasi otonom jantung dan menjadi alat yang berguna untuk memahami sistem saraf otonom yang mengatur proses-proses tertentu di dalam tubuh dengan 2 (dua) komponen utama, yaitu sistem saraf simpatetik dan parasimpatetik.

Sementara Billman, Huikiri, Sacha, dan Trimmel (2015) mengemukakan analisis HRV mencakup analisis spektral atau frekuensi domain yang menggambarkan 2 (dua) komponen utama dari sistem saraf otonom yang diartikan sebagai irama fisiologis berbeda. Hasil pengukuran power spektrum frekuensi domain $H R V$ digunakan untuk mengklasifikasikan kondisi stres mental, sebagai pengukuran efisien untuk klasifikasi stres.

\section{Intervensi Psikologi Kerekayasaan}

Dalam penelitian ini, penulis menggunakan pendekatan intervensi psikologi kerekayasaan dalam upaya mengatasi stres kerja sebagai bentuk pemahaman dan pengembangan dari manajemen stres kerja.

Munandar (2001) mengelompokkan model intervensi menjadi strategi penanganan individual, organisasional dan dukungan sosial. Sementara itu teknik-teknik yang dapat digunakan dalam psikologi kerekayasaan, yaitu : (1) kerekayasaan organisasi, (2) kerekayasaan individu (kepribadian), (3) teknik penenangan pikiran, (4) teknik penenangan melalui aktivitas fisik.

Strategi Penanganan individual bisa dilakukan dengan beberapa cara, antara lain: (a) melakukan perubahan reaksi perilaku atau perubahan reaksi kognitif, (b) melakukan relaksasi dan meditasi, (c) melakukan diet dan fitness.

Strategi penanganan organisasional dapat dilakukan dengan cara: (a) menciptakan iklim organisasional yang mendukung, (b) memperkaya desain tugas dengan memperkaya kerja, baik dengan meningkatkan faktor isi pekerjaaan atau dengan meningkatkan karakteristik pekerjaan seperti variasi skill, identitas tugas, signifikansi tugas, otonomi, dan timbal balik mungkin membawa pada pernyataan motivasional atau pengalaman berani, tanggung jawab, pengetahuan hasil-hasil, (c) mengurangi konflik dan mengklarifikasi peran organisasional. Sementara strategi dukungan sosial dibutuhkan terutama dari orang terdekat, seperti keluarga, teman sekerja, pemimpin atau orang lain untuk mengurangi stres kerja (Munandar, 2001).

Intervensi psikologi kerekayasaan adalah kemampuan penggunaan sumber daya (manusia) secara efektif untuk dapat mengatasi gangguan atau kekacauan mental dan emosional yang muncul akibat stres. Stres dalam pekerjaan dapat dicegah dan dihadapi tanpa memperoleh dampak yang negatif.

Pendekatan intervensi mangajarkan individu pekerja mengenai sifat dan sumber stres, efek stres terhadap kesehatan dan keterampilan pribadi dengan cara (a) mengubah faktor-faktor di lingkungan agar tidak merupakan pembangkit stres, (b) mengubah faktor-faktor dalam individu sehingga ambang stres dan toleransi terhadap stres meningkat sehingga dapat mempertahankan kesehatan.

\section{Metode Penelitian}

Populasi di dalam penelitian ini adalah seluruh nelayan di Pos UKK nelayan yang dibina Dinas Kesehatan Kota Cilegon berjumlah 4000 nelayan. Teknik pengambilan sampel pada penelitian ini 
menggunakan teknik purposive sampling dengan kriteria : (1) Pos UKK nelayan yang relatif kurang mendapat perhatian, yaitu : (a) Pos UKK nelayan Tanjung Peni, Citangkil Cilegon dan (b) Pos UKK nelayan Leleyan, Grogol Cilegon; (2) Pekerjaan utama sebagai nelayan. Adapun jumlah sampel (subyek) penelitian berdasarkan kriteria tersebut adalah 84 nelayan (responden). Dalam penelitian ini analisa data yang digunakan ada 3 (tiga), yaitu: (1) analisa data deskriptif (kuantitatif), (2) analisa data wawancara (kualitatif), dan (3) analisa data heart rate variability (HRV).

Instrumen penelitian diadaptasi dan dimodifikasi oleh Manurung (2017) berdasarkan konsep Igor (1997). Blue print skala stres kerja dapat dilihat pada tabel 1 di bawah ini.

Tabel 1. Blue Print Skala Stres Kerja

\begin{tabular}{cccc}
\hline No. & Dimensi & Item & Jumlah \\
\hline 1. & Intimidasi dan Tekanan & $1,6,11$ & 3 \\
2. & Ketidakcocokan dengan Pekerjaan & $2,7,12$ & 3 \\
3. & Target dan Harapan & $3,8,13$ & 3 \\
4. & Pekerjaan yang Berbahaya & $4,9,14$ & 3 \\
5. & Beban Kerja & $5,10,15$ & 3 \\
\hline & & Total Item & 15 \\
\hline
\end{tabular}

Hasil analisis data digunakan sebagai dasar pengembangan intervensi psikologi kerekayasaan sebagai upaya mengatasi stres kerja nelayan.

Berdasarkan hasil dari ketiga analisa data yang digunakan dalam metode penelitian, penulis mengembangkan upaya intervensi psikologi kerekayasaan untuk membantu mengatasi stres kerja nelayan tradisional.

\section{Hasil dan Pembahasan \\ 1. Hasil Penelitian}

\section{a. Hasil Analis a Deskriptif}

Berdasarkan nilai rata-rata yang diperoleh pada pada kelompok nelayan tradisional Tanjung Peni dan Leleyan diperoleh nilai rata-rata, yaitu 53,385. Nilai Maksimum adalah 75. Adapun kategori nilai yang ditentukan adalah sebagai berikut: nilai 15-30 (stres rendah); nilai 31-45 (stres sedang); dan 46-60 (stres cukup tinggi), dan 61-75 (stres tinggi). Berdasarkan kategori nilai yang ditetapkan penulis di atas, nilai mean nelayan di kedua lokasi tersebut tergolong cukup tinggi.

\section{b. Hasil Uji Independent Sampel t-Test}

Uji analisis data yang digunakan pada penelitian ini adalah independent sampel t-test. Berdasarkan nilai rata-rata yang diperoleh pada hasil t-test maka nilai rata-rata (mean) pada kelompok nelayan tradisional Leleyan Grogol lebih tinggi dibandingkan dengan nilai rata-rata (mean) pada kelompok Tanjung Peni Citangkil. Deskripsi nilai rata-rata pada kelompok Tanjung Peni Citangkil dan kelompok Leleyan Grogol dapat dilihat pada tabel 2 berikut.

Tabel 2. Deskripsi t-test

\begin{tabular}{|c|c|c|c|}
\hline Kelompok & N & Mean & $\begin{array}{c}\text { Standar } \\
\text { Deviasi }\end{array}$ \\
\hline $\begin{array}{c}\text { Kelompok } \\
\text { Tanjung Peni } \\
\text { Citangkil }\end{array}$ & 45 & 52,31 & 10,440 \\
\hline $\begin{array}{c}\text { Kelompok } \\
\text { Leleyan Grogol }\end{array}$ & 39 & 54,46 & 7,225 \\
\hline
\end{tabular}

Nilai rata-rata (mean) hasil analisis stres kerja pada nelayan tradisional pada kelompok Leleyan Grogol, yaitu sebesar 54,46 lebih besar dibandingkan dengan nilai rata-rata pada kelompok Tanjung Peni Citangkil yaitu 52,31. Artinya stres kerja pada kelompok Leleyan Grogol lebih tinggi dibandingkan dengan stres kerja pada kelompok Tanjung Peni Citangkil. 
Nilai signifikansi yang harus dipenuhi pada suatu penelitian, yaitu uji t lebih kecil dari $0.05(\mathrm{p}<0.05)$ dan nilai uji $t$ hitung lebih besar dari nilai $t$ tabel ( $\mathrm{t}$ hitung $>\mathrm{t}$ tabel). Hasil pengujian signifikansi terhadap hasil tes stres kerja pada kedua kelompok, yakni kelompok Tanjung Peni Citangkil dan kelompok Leleyan Grogol dapat dilihat pada tabel 3 berikut.

Tabel 3. Hasil Uji t

\begin{tabular}{|c|c|c|c|}
\hline $\begin{array}{c}\text { Kelompok } \\
\text { Nelayan }\end{array}$ & Variabel & $\begin{array}{c}\text { Nilai } \\
\mathrm{t}\end{array}$ & $\begin{array}{c}\text { Nilai } \\
\text { Signifikansi (p) }\end{array}$ \\
\hline $\begin{array}{c}\text { Tanjung } \\
\text { Peni } \\
\text { Citangkil }\end{array}$ & Stres & 4,70 & 0.000 \\
\hline $\begin{array}{c}\text { Leleyan } \\
\text { Grogol }\end{array}$ & $\begin{array}{c}\text { Stres } \\
\text { Kerja }\end{array}$ & 13,4 & 0.000 \\
\hline
\end{tabular}

Berdasarkan tabel 3 dapat dilihat bahwa nilai signifikansi pada uji t kedua kelompok adalah sebesar 0.000, nilai ini lebih besar dibandingkan 0,05. Pada kelompok nelayan Tanjung Peni Citangkil, nilai t hitung $(4,70)$ lebih besar dibandingkan dengan nilai t tabel $(2,021)$ maka dapat dinyatakan bahwa nelayan tradisional Tanjung Peni Citangkil memiliki stres kerja secara signifikan.

Sedangkan pada kelompok nelayan Leleyan Grogol, nilai t hitung $(13,4)$ lebih besar dibandingkan dengan nilai t tabel $(2,042)$ maka dapat dinyatakan bahwa nelayan tradisional kelompok Leleyan Grogol memiliki stres kerja secara signifikan.

Namun bila dibandingkan antara kedua kelompok nelayan, ditemukan bahwa stres kerja kelompok nelayan Leleyan Grogol lebih tinggi dari pada kelompok nelayan Tanjung Peni Citangkil.

\section{c. Hasil Analisis Data Wawancara}

Hasil analisis data wawancara mengungkapkan hal-hal yang terkait dengan hal-hal berikut :

\section{1). Lingkungan Kerja}

\section{a) Suhu Udara}

Secara umum para nelayan mengatakan bahwa suhu udara saat mereka sedang bekerja di siang hari terasa sangat panas dan pada malam hari terasa sangat dingin sampai menggigil. Suhu udara terasa sangat dingin ketika pukul 03.00 dini hari, hal tersebut disebabkan ketika musim angin timur atau angin selatan datang. Bahkan terkadang karena angin yang tidak menentu membuat suhu udara menjadi buruk sehingga menyebabkan badai. Kondisi suhu udara yang ekstrim panas di siang hari berefek pada peningkatan metabolisme,sehingga bisa menimbulkan stres dan lelelahan kerja, Sementara suhu di malam hari yang ekstrim dingin berefek pada munculnya hendaya yang pada akhirnya berakibat pada stres kerja dan dapat menurunkan produktivitas.

\section{b) Goncangan}

Goncangan yang dirasakan nelayan tidak menentu tergantung pada angin dan cuaca saat berlayar. Terkadang getaran menyebabkan gelombang besar yang dapat mengakibatkan perahu nelayan terguling. Kondisi ini tentunya berdampak pada stres kerja nelayan, dimana nelayan dihadapkan pada situasi yang mencemaskan.

\section{c) Limbah Industri}

Lokasi nelayan mencari ikan kebanyakan dekat dengan kawasan industri. Menurut nelayan, sebelum kawasan industri dibangun para nelayan dengan mudah mendapatkan ikan di area penangkapan, namun saat ini nelayan harus berlayar sampai ke tengah laut untuk mendapatkan hasil tangkapan. Di lain pihak, perahu yang nelayan gunakan sesungguhnya kurang kondusif untuk menangkap ikan di tengah laut.

\section{d) Kebisingan}

Kebisingan yang dirasakan para nelayan dari suara mesin kapalnya secara umum menimbulkan suara yang mengganggu dan berisik, beberapa faktor yang menyebabkan kebisingan, antara lain : jenis 
mesin kapal, mesin kapal yang kurang/tidak layak pakai, pemeliharaaan mesin yang kurang, usia mesin kapal yang kebanyakan sudah tua. Kebisingan yang terus-menerus yang dialami oleh nelayan dengan kondisi kapal sedemikian dapat menimbulkan tuli saraf.

\section{2). Cara Kerja}

Nelayan hanya memakai alat pelindung diri (APD) seperti : topi, baju berlengan panjang, dan sepatu karet. Selain APD tersebut, seharusnya para nelayan ketika melaut perlu bahkan harus menggunakan kacamata hitam dan sarung tangan karet. Kacamata hitam sangar baik dipakai nelayan untuk melindungi mata dari sinar ultraviolet, debu, dan angin. Sementara, sarung tangan karet berguna untuk melindungi tangan dari iritasi air laut yang terus-menerus dan iritasi akibat menarik tambang.

Alasan nelayan tidak menggunakan sepatu karet, kaca mata hitam dan sarung tangan karet disebabkan merasa tidak nyaman karena tidak terbiasa. Nelayan beranggapan bahwa alat tersebut dirasa merepotkan dan membahayakan saat sedang bekerja. Bagi nelayan kacamata hitam tidak diperlukan karena sudah dapat melihat dengan jelas sedangkan sarung tangan karet dipersepsikan licin dan membuat sulit saat harus menangkap ikan. Nelayan lebih memilih menggunakan sarung tangan biasa saat bekerja. Persepsi nelayan di atas cenderung keliru dan bila hal ini tidak cepat - cepat disadari, tentunya dapat berakibat munculnya berbagai penyakit akibat kerja, antara lain pterigium (selaput putih pada mata), katarak, dermatitis (kontak iritan), dsbnya.

\section{3) Manajemen Kesehatan \& Keselamatan Kerja (K3)}

Pos UKK nelayan Citangkil dan Leleyan masih kurang berfungsi efektif. Sesungguhnya Pos UKK nelayan dapat menjalankan fungsi mengembangkan manajemen K3 bagi nelayan dan keluarga. Puskesmas belum mendampingi Pos UKK nelayan secara lebih optimal untuk mengatasi berbagai permasalahan $\mathrm{K} 3$, khususnya terkait dengan kecelakaan kerja yang dialami nelayan.

Berdasarkan hasil wawancara dan observasi, pemahaman tentang manajemen K3 bagi para nelayan dirasakan masih sangat kurang. Hal ini bisa dipahami karena pelatihan manajemen K3 relatif sangat minim diadakan. Padahal pelatihan manajemen K3 sangat penting untuk membantu berbagai permasalahan kesehatan dan keselamatan kerja nelayan.

Pelatihan manajemen K3 kepada para nelayan pada umumnya dan Tim K3 Pos UKK pada khususnya belum optimal diberikan oleh Tim Kesehatan Kerja Kota Cilegon, khususnya oleh Puskesmas Citangkil dan Grogol Cilegon dalam membantu nelayan menghindari diri dari kecelakaan, ketidakamanan, dan ketidaknyamanan dalam bekerja.

Pelatihan manajemen K3 belum menjadi program rutin dan informasi pelatihan yang diberikan tidak merata sehingga nelayan masih banyak yang tidak tahu mengenai pelatihan K3 yang diberikan oleh tim kesehatan kerja. Ternyata, para nelayan yang telah mengikuti pelatihan K3 selama ini tidak banyak membantu nelayan dalam menghindari diri dari kecelakaan kerja karena belum menjadi sikap kerja dan esensi K 3 belum dipahami sepenuhnya.

Selain itu, kebanyakan nelayan tidak memiliki kesadaran diri untuk mengubah ataupun menerapkan hal-hal dalam pelatihan manajemen K3.

Manajemen K3 belum dipahami oleh para nelayan. Sebagai contoh, tidak adanya tanda-tanda bahaya apapun yang dipasang oleh tim kesehatan kerja maupun puskesmas untuk mengatasi terjadinya kebakaran. Pelatihan kebakaran belum pernah diberikan kepada nelayan. Tanda-tanda peringatan bahaya tidak ada di lokasi kerja, sehingga nelayan memasang sendiri tanda-tanda peringatan bahaya berdasarkan pengalaman sebagai nelayan, seperti menggunakan karang atau batu sebagai tanda dan menggandalkan angin dan cuaca sebagai tanda atau peringatan bahaya. Pertolongan pertama pada kecelakaan cenderung dilakukan berdasarkan pengalaman empiris sebagai nelayan.

Ternyata, dukungan fasilitas untuk menunjang K3 belum tersedia sehingga nelayan kesulitan dalam mengatasi berbagai masalah terkait K3. Nelayan berharap ada fasilitas yang menunjang K3, apalagi seperti obat-obatan saat berada di tengah laut.

Nelayan juga merasa tidak ada pertemuan evaluasi pelaksaan K3 oleh tim kesehatan kerja maupun puskesmas, sehingga nelayan tidak banyak yang tahu mengenai kegiatan kampanye yang berkaitan 
dengan K3 yang melibatkan nelayan setempat. Hal ini disebabkan oleh informasi yang tidak merata di lingkungan nelayan sehingga banyak program tidak berjalan dengan baik.

\section{d. Hasil Analisa Data Heart Rate Variability (HRV)}

$H R V$ memberikan gambaran mengenai stres kerja pada nelayan tradisional di pesisir Cilegon Banten. Hasil HRV berikut menjelaskan mengenai stress resistance (coping stress), stress index (psikis), dan fatigue index (kelelahan). Tabel 4 berikut menguraikan hasil HRV pada nelayan tradisional di pesisir pantai Cilegon.

Tabel 4. Heart Rate Variability (HRV) Nelayan Leleyan Grogol

\begin{tabular}{|c|c|c|c|c|c|}
\hline & $\begin{array}{c}\text { Sangat } \\
\text { Buruk }\end{array}$ & Buruk & Normal & Bagus & $\begin{array}{c}\text { Sangat } \\
\text { Bagus }\end{array}$ \\
\hline $\begin{array}{c}\text { Stress } \\
\text { Resistance } \\
\text { (Coping Stres) }\end{array}$ & $19 \%$ & $21 \%$ & $60 \%$ & $0 \%$ & $0 \%$ \\
\hline $\begin{array}{c}\text { Stress Index } \\
\text { (Psikis) }\end{array}$ & $14 \%$ & $24 \%$ & $50 \%$ & $12 \%$ & $0 \%$ \\
\hline $\begin{array}{c}\text { Fatigue Index } \\
\text { (Kelelahan) }\end{array}$ & $16 \%$ & $45 \%$ & $34 \%$ & $2 \%$ & $3 \%$ \\
\hline
\end{tabular}

Pada tabel 4 di atas, berdasarkan hasil tes $H R V$ dapat dilihat bahwa nelayan tradisional di Leleyan Grogol menunjukkan coping stress yang kurang baik, dimana skala buruk dan sangat buruk cukup besar, yaitu $40 \%$; indeks stres psikis pada level buruk dan sangat buruk $38 \%$; dan indeks kelelahan (fatigue) berada pada level cukup memprihatinkan dengan jumlah $61 \%$ pada level buruk dan sangat buruk.

Tabel 5. Heart Rate Variability (HRV) Nelayan Tanjung Peni Citangkil

\begin{tabular}{|c|c|c|c|c|c|}
\hline & $\begin{array}{c}\text { Sangat } \\
\text { Buruk }\end{array}$ & Buruk & Normal & Bagus & $\begin{array}{c}\text { Sangat } \\
\text { Bagus }\end{array}$ \\
\hline $\begin{array}{c}\text { Stress } \\
\text { Resistance } \\
\begin{array}{c}\text { Coping } \\
\text { Stress) }\end{array}\end{array}$ & $8 \%$ & $7 \%$ & $67 \%$ & $13 \%$ & $5 \%$ \\
\hline $\begin{array}{c}\text { Stress } \\
\text { Index } \\
\text { (Psikis) }\end{array}$ & $6 \%$ & $10 \%$ & $58 \%$ & $21 \%$ & $5 \%$ \\
\hline $\begin{array}{c}\text { Fatigue } \\
\text { Index } \\
\text { (Kelelahan) }\end{array}$ & $5 \%$ & $20 \%$ & $58 \%$ & $10 \%$ & $7 \%$ \\
\hline
\end{tabular}

Berdasarkan tabel 5, hasil tes $H R V$ pada nelayan tradisional di wilayah Tanjung Peni, Citangkil menunjukkan stress resistance (coping stress), dan stress index (psikis), dan fatigue index relatif kurang baik. Ada $15 \%$ nelayan berada pada level coping stress buruk dan sangat buruk; indeks stres (psikis) berjumlah $16 \%$ pada level buruk dan sangat buruk; dan indeks kelelahan sebesar $25 \%$ dalam level buruk dan cukup buruk.

\section{Pembahasan}

Hasil penelitian menunjukkan bahwa terdapat tingkat stres yang cukup tinggi pada nelayan tradisional di pesisir pantai Cilegon Banten. Tingkat stres pada kelompok nelayan tradisional Leleyan Grogol lebih tinggi dibandingkan dengan kelompok Tanjung Peni Citangkil.

Data ini didukung dengan hasil tes Heart Rate Variability (HRV) pada nelayan tradisional di wilayah Leleyan Grogol menunjukkan stress resistance (coping stress), dan stress index (psikis), dan fatigue index lebih buruk dibandingkan dengan nelayan di Tanjung Peni Citangkil. 
Hal ini bisa dipahami karena para nelayan di Leleyan Grogol kebanyakan tidak berdomisili di sekitar pesisir, Selain itu, aktivitas utama nelayan bukan hanya nelayan. Berbeda dengan nelayan Tanjung Peni Citangkil yang kebanyakan berdomisili di pesisir dan sekitarnya serta pekerjaan sebagai nelayan lebih sebagai aktivitas utama. Situasi ini menyebabkan coping stress, indeks stres psikis dan kelelahan nelayan di Leleyan Grogol menjadi lebih tinggi.

Kondisi nelayan yang kelelahan saat bekerja sangat memengaruhi produktivitas nelayan saat melaut, karena untuk melaut dibutuhkan stamina yang kuat dan fisik yang sehat agar dapat memperoleh hasil yang maksimal. Sejalan dengan hal tersebut, nelayan masih menggunakan alat tradisional untuk menangkap ikan, dengan menggunkan alat-alat tradisional maka semua masih dikerjakan dengan menggunakan tenaga manusia. Hasil penelitian ini membuktikan bahwa tingkat stres kerja yang dialami oleh nelayan tradisional di pesisir pantai Cilegon Banten membuat nelayan kesulitan mencari nafkah yang berdampak pada kesejahteraan nelayan tradisional yang belum tercapaidengan baik.

Peneliti menemukan bahwa program yang dijalankan oleh pemerintah daerah setempat di wilayah Cilegon Banten dalam upaya mensejahterakan nelayan belum berjalan dengan baik. Hal ini dapat dilihat dari manajemen, komunikasi dan pelatihan K3 belum terealisasi dengan baik. Banyak nelayan belum mendapat pengetahuan dan keterampilan mengenai K3 yang baik dan benar. Meskipun tim kerja seperti Pos UKK maupun puskesmas sudah tersedia, informasi tidak tersampaikan dengan baik kepada nelayan tradisional di pesisir Pantai Cilegon.

Pelayanan kesehatan yang tersedia di perkampungan nelayan wilayah Tanjung Peni Citangkil maupun Leleyan Grogol dirasakan belum berjalan dengan baik. Pelayanan yang lambat dan tenaga media yang tidak siap siaga merupakan hal yang paling banyak dikeluhkan nelayan. Meskipun nelayan tradisional di pesisir pantai Cilegon Banten sudah mengetahui adanya asuransi kesehatan, nelayan berpikir tidak dapat bekerja dengan tenang karena banyak kebutuhan yang harus dipenuhi seperti mesin, peralatan, dan perawatan kapal yang mahal. Hal ini membuat nelayan di pesisir pantai Cilegon memiliki tingkat stres yang tinggi.

Dari hasil penelitian mengenai stres kerja pada nelayan tradisional di pesisir Pantai Cilegon Banten, salah satu upaya progresif untuk mengatasi stres kerja pada nelayan adalah dengan melakukan intervensi psikologi kerekayasaan. Upaya intervensi psikologi kerekayasaan dalam mengatasi stres dalam pekerjaan nelayan dapat dicegah timbulnya dan dapat dihadapi tanpa memperoleh dampak yang negatif. Upaya dimaksud dikenal sebagai pendekatan manajemen stres (tata kelola stres), yang lebih dari pada sekedar mengatasi stres kerja nelayan, tetapi juga belajar mencegah dan menanggulangi stres kerja nelayan secara adaptif dan efektif.

\section{Pengembangan Intervensi Psikologi Kerekayasaan sebagai Upaya Mengatasi Stres Kerja Nelayan}

Berdasarkan analisis data dan pembahasan di atas perlu dikembangkan model intervensi psikologi kerekayasaan sebagai upaya mengatasi kompleksitas masalah stres kerja yang dialami oleh nelayan tradisional di Tanjung Peni Citangkil dan Grogol Cilegon.

Adapun model pengembangan intervensi psikologi kerekayasaan yang dapat diaplikasikan bagi para nelayan diuraikan berikut ini :

a. Strategi Penanganan Individual

Strategi yang dikembangkan secara pribadi atau individual. Strategi individual ini bisa dilakukan dengan beberapa cara, antara lain:

1) Melakukan perubahan reaksi perilaku atau perubahan reaksi kognitif. Artinya, jika seorang nelayan merasa dirinya ada kenaikan ketegangan, nelayan tersebut seharusnya istirahat terlebih dahulu. Cara time out atau istirahat ini bisa macam-macam, seperti istirahat sejenak sambil melihat keindahan laut sekitar, istirahat dengan berbaring atau duduk sebentar, membasuh muka air dingin atau berwudhu bagi yang beragama Islam, dan sebagainya.

2) Melakukan relaksasi dan meditasi Kegiatan relaksasi dan meditasi ini bisa dilakukan di rumah atau hari-hari saat sedang tidak melaut. Dengan melakukan relaksasi, nelayan dapat membangkitkan perasaan rileks dan nyaman. Dengan demikian nelayan yang melakukan 
relaksasi diharapkan dapat mentransfer kemampuan dalam membangkitkan perasaan rileks ke dalam pekerjaannya di mana nelayan mengalami situasi stres. Beberapa cara meditasi yang biasa dilakukan adalah dengan menutup atau memejamkan mata, menghilangkan pikiran yang mengganggu,kemudian perlahan lahan mengucapkan doa.

3) Melakukan diet dan fitness. Beberapa cara yang bisa ditempuh adalah mengurangi masukan atau konsumsi makanan berlemak, memperbanyak konsumsi makanan yang bervitamin seperti buah-buahan dan sayur-sayuran, dan banyak melakukan olahraga, seperti lari secara rutin, tenis, bulutangkis, dan sebagainya. Hal ini dapat membantu nelayan dalam meningkatkan daya tahan tubuh agar fit dan tidak mudah kelelahan.

b. Strategi Penanganan Organisasional

Strategi ini didesain oleh manajemen untuk menghilangkan atau mengontrol penekan tingkat organisasional untuk mencegah atau mengurangi stres kerja untuk pekerja individual. Manajemen stres melalui organisasi dapat dilakukan dengan:

1) Menciptakan iklim organisasi yang mendukung. Dalam hal ini peran Tim Kesehatan Kerja Kota Cilegon, Puskesmas Kecamatan, dan Pos UKK untuk membantu memantau kesehatan nelayan sangatlah penting, sehingga nelayan juga ikut menjaga kesehatannya agar stres kerja nelayan dapat berkurang/teratasi. Struktur dan proses struktural dapat menciptakan iklim yang lebih mendukung bagi pekerja, memberikan individu pekerja lebih banyak kontrol terhadap pekerjaan, dan mungkin mencegah atau mengurangi stres kerja yang muncul.

2) Memperkaya desain tugas-tugas dengan memperkaya kerja, baik dengan meningkatkan faktor isi pekerjaaan (seperti tanggung jawab, pengakuan, dan kesempatan untuk pencapaian, peningkatan, dan pertumbuhan) atau dengan meningkatkan karakteristik tugas/ pekerjaan seperti variasi skill, identitas tugas, signifikansi tugas, otonomi, dan timbal balik mungkin membawa pada pernyataan motivasional atau pengalaman berani, tanggung jawab, pengetahuan hasil-hasil. Pengetahuan baru untuk nelayan tradisional dalam meningkatkan hasil tangkapan sangatlah diperlukan. Tugas nelayan, selain menangkap ikan juga bisa juga meningkatkan nilai hasil tangkapan dengan cara mengolah hasil tangkapan sehingga memberikan nilai tambah. Nelayan juga bisa mengembangkan peran dan fungsi pemasaran hasil dalam bentuk koperasi atas paguyuban nelayan sehingga nilai jual hasil tangkapan memberikan keuntungan bagi para nelayan.

3) Mengurangi konflik dan upaya mengklarifikasi berbagai peran organisasional. Konflik peran dan hal terkait ketidakjelasan diidentifikasi lebih awal sebagai sebuah penekan individual utama. Terutama konflik mengenai wilayah atau area nelayan dalam menangkap ikan. Kerap kali konflik terjadi karena wilayah menangkap ikan antara nelayan satu dengan yang lain berdekatan sehingga menimbulkan konflik. Ini mengacu pada manajemen untuk mengurangi konflik dan mengklarifikasi berbagai peran organisasional sehingga faktor penyebab stres dapat dikurangi, bahkan dihilangkan. Salah satu upaya untuk terhindar dari konflik antar nelayan adalah dengan membuat kesepakatan mengenai wilayah menangkap ikan dan memberikan sanksi bagi yang melanggar.

\section{c. Strategi Dukungan Sosial}

Dibutuhkan dukungan sosial terutama orang terdekat, seperti keluarga, teman sesama nelayan, pemimpin atau orang lain untuk mengurangi stres kerja (Munandar, 2001). Lebih jauh Munandar mengemukakan, dibutuhkan komunikasi yang baik pada semua pihak, sehingga dukungan sosial dapat diperoleh. Nelayan dapat mengajak berbicara orang lain tentang masalah yang dihadapi, atau setidaknya ada tempat mengadu atas keluh kesahnya.

\section{Kesimpulan dan Saran}

\section{Kesimpulan}

Berdasarkan analisis data dan pembahasan mengenai analisis stres kerja dan intervensi psikologi kerekayasaan pada nelayan tradisional Tanjung Peni Citangkil dan Leleyan Grogol di pesisir pantai Cilegon Banten, diperoleh kesimpulan berikut :

a. Terdapat stres kerja yang cukup tinggi pada nelayan tradisional di Tanjung Peni Citangkil dan Leleyan Grogol pesisir pantai Cilegon Banten. Hal ini dapat dibuktikan dengan adanya $t$ hitung $>t$ tabel. Selain hasil uji t,juga didukung dengan hasil analisis $H R V$. 
b. Stres kerja pada kelompok nelayan Leleyan Grogol lebih tinggi dibandingkan dengan stres kerja pada kelompok nelayan Tanjung Peni Citangkil. Hal ini dapat dibuktikan dengan adanya t hitung kelompok nelayan Leleyan Grogol lebih tinggi, dibandingkan dengan kelompok nelayan Tanjung Peni Citangkil. Selain itu, data t-test juga didukung dengan hasil HRV dalam stress resistance, stress index, dan fatigue index nelayan Leleyan Grogol lebih buruk dibanding Nelayan Tanjung Peni Citangkil.

c. Hasil data wawancara menunjukkan bahwa hal yang menyebabkan stres kerja pada nelayan tradisional di pesisir Pantai Cilegon Banten adalah : a) lingkungan kerja yang tidak mendukung (suhu udara, goncangan, limbah industri, dan kebisingan dari mesin kapal); b) cara kerja yang tidak ergonomis, dan c) manajemen K3 yang buruk.

d. Diperlukan pengembangan intervensi psikologi kerekayasaan untuk membantu mengatasi stres kerja yang dihadapi nelayan dengan menerapkan strategi penanganan individual, strategi penanganan organisasional, dan strategi dukungan sosial. Upaya ini sekaligus diharapkan dapat memberikan dukungan positif bagi peningkatan produktivitas kerja nelayan.

\section{Ke terbatas an Penelitian}

Peneliti menyadari bahwa penelitian ini memiliki beberapa keterbatasan yang dapat memengaruhi hasil penelitian. Keterbatasan tersebut adalah sebagai berikut :

a. Subyek penelitian yang terbatas dan masih kurang dan hasil penelitian hanya menggambarkan analisis deskriptif, analisis wawancara, dan analisis hasil tes HRV

b. Keterbatasan waktu yang dimiliki peneliti dikaitkan dengan jadwal melaut nelayan, sehingga kesempatan untuk memperdalam, mengembangkan, dan memperluas hasil penelitian terbatas.

\section{Saran}

Berdasarkan hasil penelitian dan kesimpulan yang diperoleh, maka saran yang dapat diberikan adalah sebagai berikut :

a. Penelitian mendatang perlu menekankan pendekatan kuantitatif yang bukan hanya mengungkapkan analisis deskriptif, hasil data wawancara, dan analisis $H R V$, melainkan menekankan pada analisis regresi atau SEM untuk membuktikan pengaruh independen variabel terhadap dependen variabel.

b. Penelitian di masa mendatang perlu mengembangkan mix method untuk menggambarkan hasil penelitian yang lebih komprehensif dan holistik.

c. Penelitian selanjutnya hendaknya lebih memperhatikan jadwal melaut para nelayan sehingga pengumpulan data penelitian dapat berjalan lebih optimal.

d. Perhatian pemerintah, khususnya Tim Kesehatan Kerja dan Puskesmas Kecamatan perlu lebih optimal dalam membantu manajemen K3, serta sarana dan prasarana yang masih belum tersedia pada nelayan tradisional di pesisir Pantai Cilegon Banten.

e. Pos UKK perlu lebih meningkatkan fungsi dan perannya untuk membantu para nelayan memahami bahwa stres kerja dibutuhkan untuk meningkatkan kualitas dan produktivitas kerja.

f. Program intervensi psikologi kerekayasaan perlu lebih dikembangkan oleh berbagai komponen, baik pemerintah, swasta, LSM, dan pemerhati nelayan.

\section{DAFTAR PUSTAKA}

Billman, G.E., Huikiri, H.V., Sacha, J. \& Trimmel, K. (2015). An introduction to heart rate variability: methodological considerations and clinical applications. Frontiers in Physiology, V.6: 55 (2015.Published online 2015 Feb 25. doi: 10.3389/fphys.2015.00055.

Caverley, N. (2005). Civil service resilience and coping, International Journal of Public Sector Management, Vol. 18 No. 5, 2005, pp. 401-413.

Cox, T., Griffiths, A., dan Rial-G.E. (2000). Research on work-related stress. European Agency for Safety and Health at Work.

Makara (2012). Sosial humaniora, vol 16, No 1, Juli 2012.

Munandar (2001). Psikologi industri dan organisasi. Jakarta: UI Press

NIOSH (2000). Stress at work. Columbia : NIOSH 
Novani, N.P. \& Prihatmanto, A.S. (2016). Heart rate variability frekuensi domain untuk deteksi stres mental dan influenza menggunakan svmclassifier.Tesis.Bandung: ITB.url=https://doi.org/10.5281/zenodo.59500

Olpin, M. \& Hesson, M. (2012).Stress management for life: a research-based experiential approach. Wardsworth, Cengage Learning

Oxington, K.V. (2008).Psychology of Stress.New York: Nova Science Publishers

Pusat Data dan Informasi Kesehatan RI (2015)

Redfern,.D.C. Rees, C.J. \& Rowlands, K.E. (2008) "Occupational stress: consensus or divergence? A challenge for training and development specialists", Industrial and Commercial Training,Vol.40 Issue: 6, pp. 287-294,https:// doi.org/10.1108/00197850810900039

Santrock, J. W. (2003). Psychology (7th ed.). Boston: McGraw-Hill.

Tarwaka (2013). Ergonomi industri dasar-dasar pengetahuan ergonomi dan aplikasi di tempat kerja.Surakarta:Harapan Press.

$* * * * *$ 